\title{
Pengaruh Komunikasi Dan Disiplin Kerja Terhadap Kinerja Guru SDN Parakan - Tangerang Selatan
}

\author{
Ahmad Sumali, Alfa Yudha Pratama \\ Dosen Fakultas Ekonomi Universitas Pamulang \\ Email :dosen01562@unpam.ac.id
}

\begin{abstract}
ABSTRAK
Tujuan dari penelitian adalah mengetahui pengaruh komunikasi dan Disiplin Kerja terhadap Kinerja Guru pada SDN Parakan Tangerang Selatan.

Metode penelitian yang digunakan adalah bersifat asosiatif kuantitatif, metode pengumpulan data dengan menyebar kuesioner yang kemudian diolah dengan menggunakan analisis regresi linier berganda. Uji yang digunakan untuk menguji instrumen penelitian berupa uji validitas dan uji reliabilitas. Uji regresi linier berganda, uji kolerasi, uji determinasi dan uji hipotesis menggunakan uji t dengan bantuan SPSS Versi 24. Populasi yang digunakan dalam penelitian ini adalah sebanyak 38 pegawai, dengan jumlah sampel dengan teknik penarikan sample teknik sampling jenuh.

Berdasarkan hasil penelitian diketahui variabelKomunikasi (X1) berpengaruh positif dan signifikan terhadap Kinerja Guru (Y) dengan nila korelasi sebesar 0,703 artinya memiliki pengaruh yang kuat. Koefisien determinasi sebesar 49,4\%. Uji hipotesis diperoleh $\mathrm{t}$ hitung $>\mathrm{t}$ tabel atau $(5,927>2,028)$, hal ini diperkuat dengan probability signifikansi $0,000<0,05$, dengan demikian $\mathrm{H} 0$ ditolak dan $\mathrm{H} 1$ diterima artinya terdapat pengaruh positif dan signifikan antara Komunikasi terhadap Kinerja Guru pada SDN Parakan Tangerang Selatan.Disiplin kerja (X2) berpengaruh positif dan signifikan terhadap kinerja guru $(\mathrm{Y})$ dengan nilai korelasi sebesar 0,670 artinya memiliki pengaruh yang kuat. Koefisien determinasi sebesar $44,9 \%$. Uji hipotesis diperoleh $t$ hitung $>\mathrm{t}$ tabel atau $(5,412>2,028)$, hal ini diperkuat dengan probability signifikansi $0,000<0,05$, dengan demikian $\mathrm{H} 0$ ditolak dan $\mathrm{H} 2$ diterima artinya terdapat pengaruh positif dan signifikan antara disiplin kerja (X2) terhadap kinerja guru (Y) pada SDN Parakan Tangerang Selatan. Komunikasi (X1) dan Disiplin kerja (X2) berpengaruh positif dan signifikan terhadap kinerja guru $(\mathrm{Y})$ dengan persamaan regresi $\mathrm{Y}=9,725+0,480 \mathrm{X} 1+$ $0,351 X 2$. Nilai korelasi diperoleh sebesar 0,758 artinya variabel bebas dengan variabel terikat memiliki pengaruh yang kuat dengan koefisien determinasi atau pengaruh secara simultan sebesar $57.4 \%$ sedangkan sisanya sebesar $42.6 \%$ dipengaruhi faktor lain. Uji hipotesis diperoleh nilai F hitung $>\mathrm{F}$ tabel atau $(23,621$ $>2,870$ ), hal tersebut juga diperkuat dengan probability signifikansi $0,000<0,05$. Dengan demikian $\mathrm{H} 0$ ditolak dan $\mathrm{H} 3$ diterima. Artinya terdapat pengaruh positif dan signifikan secara simultan antara komunikasi dan disiplin kerja terhadap kinerja guru pada SDN Parakan Tangerang Selatan..
\end{abstract}

Kata kunci : Komunikasi, Disiplin Kerja, Kinerja Guru 


\section{PENDAHULUAN}

\section{Latar Belakang}

Komunikasi sangat lah berguna untuk di dunia kerja maupun untuk di dunia belajar mengajar. Terutama dalam bidang pendidikan, apa bila terjadi komunikasi yang baik antara guru dengan siswa, maka siswa tersebut akan sangat mudah memahami pelajaran yang mereka terima. Dalam dunia kerjapun tidak kalah penting nya, komunikasi yang baik akan memudahkan perusahaan tersebut untuk mencapai visi dan misi yang sudah di tetapkan oleh perusahaan.

Dalam dunia nyata keberhasilan seorang guru untuk mendidik para siswa nya harus di mulai dengan komunikasi yang baik, supaya para siswa dapat memahami ilmu yang di berikan oleh guru nya dengan baik. Komunikasi yang terjalin di dalam sekolah tidak hanya antara para guru dan murid, namun kesuksesan komunikasi didalam sekolah juga di mulai dari hubungan yang baik antara kepala sekolah terhadap para guru, maupun komunikasi yang terjalin sesama guru.

Tidak hanya dalam komunikasi, guru pun harus memberikan contoh disiplin terhadap para siswa nya, kebanyakan siswa jaman sekarang tidak memiliki jiwa disiplin, maka dari itu peran guru pun sangat penting untuk membentuk kararter siswa itu sendiri, mungkin dengan cara disiplin kerja. Guru guru pun mampu mengajarkan disiplin kepada siswa nya melalui ke giatan sehari hari, contoh nya iyalah datang tepat waktu saat jam pelajaran di mulai, dan memberikan hukuman kepada siswa nya yang datang terlambat, sehingga siswa tersebut memiliki sisi jera untuk mengulangi nya kembali, dan di situ lah sifat disiplin siswa mulai terbentuk.

Faktor yang mempengaruhi bagus atau tidak nya nilai siswa adalah kinerja guru nya tersebut, apa bila kinerja guru tersebut telah maksimal akan berpengaruh kepada nilai siswa nya pula, peran guru pun sangat ber pengaruh kepada tingkat perkembangan siswa nya baik secara akademik mau pun non akademik. Kinerja guru menurut Supardi (2014:54) merupakan kemampuan seorang guru dalam melaksanakan tugas pembelajaran di sekolah dan ber tanggung jawab atas peserta didik di bawah bimbingannya dengan meningkatkan prestasi peserta didik nya. Jadi tugas guru sebagai tenaga pendidik harus dapat menyampaikan ilmu dan materi pembelajaran kepada para siswa nya, hasil yang harus di capai oleh guru sebagai tenaga pendidik adalah meningkat nya nilai para siswa dari tahun ke tahun, namun apa bila guru yang berperan sebagai tenaga pendidik masih tidak memiliki rasa di siplin yang tinggi, bagaimana siswa akan terbentuk nya karakter yang baik.

Berdasarkan permasalahan yang dihadapi oleh guru, maka penulis tertarik untuk melakukan penelitian dengan judul Pengaruh Komunikasi Dan Disiplin Kerja Terhadap Kinerja Guru SDN Parakan - Tangerang Selatan. 


\section{Identifikasi Masalah}

Dalam identifikasi masalah ini, penulis pun akan merumuskan beberapa masalah pada berikut:

a. Komunikasi yang terjalin antara guru sebagai tenaga pengajar kepada siswa belum berjalan maksimal disebabkan karena masih ada beberapa guru yang absen.

b. Komunikasi antara sesama guru masih tidak maksimal.

c. Absensi guru tidak maksimal pada bulan bulan tertentu.

d. Dalam beberapa kasus guru belum memebrikan contoh yang baik.

e. Tidak ada nya guru pengganti di saat kelas kosong yang di sebabkan karena guru yang bersangkutan beerhalangan untuk hadir.

f. Kurang di siplin nya guru sebagai tenaga pendidik.

g. Belum tercapai nya visi dan misi sekolah.

\section{Perumusan Masalah}

Berdasarkan identifikasi masalah yang ada, maka penulis mencoba menuliskan masalah sebagai berikut:

a. Bagaimana pengaruh komunikasi terhadap kinerja guru SDN Parakan Tangerang Selatan.

b. Bagaimana pengaruh disiplin kerja guru SDN Parakan Tangerang Selatan.

c. Bagaimana pengaruh komunikasi dan disiplin kerja secara simultan terhadap kinerja guru SDN Parakan Tangerang Selatan.

\section{Hipotesis Penelitian}

Hipotesis berdasarkan pada perumusan masalah dan tujuan penelitian, maka hipotesis dalam penelitian ini adalah:

H1: Diduga terdapat pengaruh komunikasi terhadap kinerja guru SDN Parakan Tangerang Selatan.

$\mathrm{H} 2$ : Diduga terdapat pengaruh disiplin terhadap kinerja guru SDN Parakan Tangerang Selatan.

H3: Diduga terdapat pengaruh komunikasi dan disiplin kerja terhadap kinerja guru SDN Parakan Tangerang Selatan.

\section{TINJAUAN PUSTAKA}

\section{Komunikasi}

dalam $\begin{aligned} & \text { Istilah komunikasi atau } \\ & \text { bahasa inggris }\end{aligned}$
communication berasal dari kata latin communication, dan bersumber dari kata communis yang berarti sama. Sama disini maksud nya adalah sama makna. Menurut Onong Uchjana Effendi dalam Ilmu Komunikasi Teori dan Praktek (2016:9), Jadi kalau dua orang terlibat dalam komunikasi, missal dalam bentuk percakapan, maka komunikasi akan terjadi atau berlangsung selama ada kesamaan makna mengenai apa yang di percakapkan.

Menurut Keith Davis dalam Mangkunegara (2013:145) mengemukakan komunikasi adalah pemindahan informasi dan pemahaman dari seseorang kepada orang lain.

Menurut Andrew E. Sikula dalam mangkunegara (2013:145) mengemukakan komunikasi adalah proses pemindahan informasi, pengertian, dan pemahaman dari seseorang, suatu 
tempat, atau sesuatu kepada sesuatu, tempat, atau orang lain. Berdasarkan pendapat para ahli di atas, maka komunikasi dapat diartikan sebagai proses pemindahan suatu informasi, ide, pengertian dari seseorang kepada orang lain dengan harapan orang lain tersebut dapat menginterpretasikan sesuai dengan tujuan yang dimaksud.

\section{Disiplin}

Dalam bahasa disiplin berasal dari bahasa latin, yaitu dari kata discipline yang berarti latihan atau pendidikan kesopanan dan kerohanian serta pengembangan tabiat. Kata disiplin sering menjadi suatu ukuran yang bernilai positif yang biasanya dijadikan indikasi orang orang sukses untuk mencapai kenginan dan citacitanya dalam memajukan sebuah organisasi.

Berdasarkan pendapat Keith Davis dalam Anwar Prabu Mangkunegara (2013:129), disiplin kerja dapat di artikan sebagai pelaksanaan manajemen untuk memperteguh pedomanpedoman organisasi. Disiplim yang baik itu mencerminkan besarnya rasa tanggung jawab seseorang terhadap tugas-tugas yang diberikan kepadanya.

Menurut singodimedjo dalam Edy Sutrisno (2016:86), mengatakan disiplin adalah sikap kesediaan dan kerelaan seseorang untuk mematuhi dan menaati norma-norma peraturan yang berlaku disekitarnya.

Latainer, Soediono dalam Edy Sutrisno (2016:87), mengemukakan disiplin kerja sebagai suatu kekuatan yang berkembang di dalam tubuh guru dan menyebabkan guru dapat menyesuaikan diri dengan sukarela pada keputusan, peraturan, dan nilai-nilai tinggi dari pekerjaan dan perilaku.

Dari beberapa pendapat tersebut dapat dirumuskan bahwa yang dimaksut dengan disiplin adalah sikap hormat terhadap peraturan dan ketetapan perusahaan, yang ada dalam diri guru, yang menyebabkan ia dapat menyesuaikan diri dengan sukarela pada peraturan dan ketetapan perusahaan.

\section{Kinerja}

Istilah kinerja berasal dari kata job performance atau actual performance (prestasi kerja atau prestasi sesungguhnya yang dicapai seseorang). Pengertian kinerja adalah hasil kerja secara kualitas dan kuantitas yang dicapai oleh seorang pegawai dalam melaksanakan tugasnya sesuai dengan tanggung jawab yang diberikan kepadanya. Anwar Prabu Mangkunegara (2013:67).

Definisi kinerja yang dikemukakan Bambang Kusriyanto dalam Mangkunegara, Evaluasi Kinerja SDM (2017:9) adalah perbandingan hasil yang dicapai dengan peran serta tenaga kerja persatuan waktu (lazimnya perjam).

Fautisno Cardosa Gomes dalam Mangkunegara, Evaluasi Kinerja SDM (2017:9) mengemukakan kinerja guru sebagai ungkapan seperti output, efesiensi serta efektivitas sering dihubungkan dengan produktivitas. Oleh karena itu disimpulkan bahwa kinerja adalah 
prestasi kerja atau hasil kerja baik kualitas maupun kuantitas yang dicapai SDM persatuan periode waktu dalam melaksanakan tugas kerjanya sesuai dengan tanggung jawab yang diberikan kepadanya.

Dari beberapa pendapat diatas mengenai kinerja, maka dapat disimpulkan bahwa kinerja adalah hasil kerja atau prestasi kerja seseorang atau organisasi baik dari segi kualitas maupun kuantitas dan dapat dipertanggung jawabkan sesuai dengan perannya yang disertai dengan kemampuan, kecakapan dan keterampilan dalam menyelesaikan pekerjaannya.

\section{METODE PENELITIAN}

Metode penelitian yang digunakan adalah bersifat asosiatif kuantitatif, metode pengumpulan data dengan menyebar kuesioner yang kemudian diolah dengan menggunakan analisis regresi linier berganda. Uji yang digunakan untuk menguji instrumen penelitian berupa uji validitas dan uji reliabilitas. Uji regresi linier berganda, uji kolerasi, uji determinasi dan uji hipotesis menggunakan uji t dengan bantuan SPSS Versi 24. Populasi yang digunakan dalam penelitian ini adalah sebanyak 38 pegawai, dengan jumlah sampel dengan teknik penarikan sample teknik sampling jenuh.

\section{PEMBAHASAN}

\section{Pembahasan Deskriptif.}

Pembahasan deskriptif, dimaksudkan untuk eksplorasi dan klarifikasi mengenai suatu fenomena atau kenyataan sosial, dengan jalan mendeskripsikan sejumlah variabel yang berkenaan dengan masalah yang diteliti.

a. Keadaan atau kriteria obyek yang diteliti berdasar pada variabel komunikasi $\left(\mathrm{X}_{1}\right)$.

Komunikasi merupakan proses yang dimulai dengan defisiensi fisiologis atau psikologis yang menggerakkan perilaku atau dorongan yang ditujukan untuk tujuan atau insentif. Dengan demikian, kunci untuk memahami proses komunikasi bergantung pada pengertian dan hubungan antara kebutuhan, dorongan dan insentif.

Hal ini dibuktikan dengan melihat secara keseluruhan untuk kuesioner variabel komunikasi $\left(\mathrm{X}_{1}\right)$ diperoleh ratarata score 4.09 dengan kriteria baik. Dari sepuluh indikator tersebut yang mendapatkan ratting score yang paling rendah berada pada nomor satu yaitu pada pernyataan kepala sekolah mampu memberikan arahan dan masukan pada semua komponen sumberdaya yang ada disekolah dengan score 3,74 termasuk dalam kategori baik.

Namun untuk lebih baik lagi maka lembaga harus secara kontinyu mereview tentang kebijakan penyampaian informasi kepada pegawai agar lebih dapat dipahami dan tidak menimbulkan interpretasi yang berbeda

b. Keadaan atau kriteria obyek yang diteliti berdasar pada variabel disiplin kerja $\left(\mathbf{X}_{2}\right)$.

Kedisiplinan yang di terapkan dan dipercontohkan 
guru dalam lingkunngan sekolah mempunyai arti dan makna yang sangat luas untuk memajukan sekolah melalui sikap, prilaku dan perbuatan sesuai dengan peraturan dari sekolah yang telah ditetapkan, baik secara tertulis maupun tidak tertulis, oleh karenanya salah satu faktor yang menjadi pertimbangan kepala sekolah dalam meningkatkan kinerja adalah disiplin kerja guru.

Hal ini dibuktikan dengan melihat secara keseluruhan untuk kuesioner variabel disiplin kerja (X2) diperoleh rata-rata score 4.13 dengan kriteria baik. Dari sepuluh indikator tersebut yang mendapatkan ratting score yang paling rendah adalah pada pernyataan aturan organisasi dapat diterapkan dengan baik tanpa tebang pilih dimana hanya mencapai rata-rata score 3,74 termasuk dalam kategori baik.

Namun untuk lebih baik lagi perusahaan harus lebih konsisten menerapkan atruan yang dibuat sehingga guru dapat menunjukkan kesetiaan dan ketaatannya terhadap aturan-aturan yang berlaku bagi sebuah organisasi serta dapat menunjukkan kesetiaan dan ketaatannya terhadap normanorma yang berlaku bagi sebuah organisasi tersebut.

c. Keadaan atau kriteria obyek yang diteliti berdasar pada variabel kinerja guru (Y).

Kinerja guru bisa dilihat dari berbagai sudut pandang, tergantung pada tujuan dari masing-masing organisasi yang menghubungkan antara output, kinerja, efisiensi, efektivitas dengan produktivitas. Secara umum, kinerja guru menunjukkan kepada rasio output kinerja organisasi dan penentuan jumlah sumber daya yang dipakai untuk menghasilkan outcome tersebut, kinerja guru juga dikaitkan dengan kualitas output, yang diukur berdasarkan beberapa standar yang lebih ditetapkan sebelumnya.

Hal ini dibuktikan dengan melihat jawaban responden responden secara keseluruhan untuk kuesioner variabel kinerja guru (Y) diperoleh ratarata score 4.04 dengan kriteria baik. Dari kesepuluh indikator tersebut yang mendapatkan ratting score yang paling rendah adalah pada pernyataan saya selalu memberikan ide-ide kepada guru lain untuk sistem mengajar dengan baik dimana hanya mencapai score 3,76 termasuk dalam kategori baik.

Namun untuk lebih baik lagi sekolah harus lebih intensif terhadap sumber-sumber konversi seperti tenaga pengajar dan fasilitas yang digunakan dalam kegiatan belajar mengajar yang jika diukur secara tepat akan benarbenar menunjukkan suatu efisiensi, maka sikap mental guru harus diarahkan pada pandangan bahwa seklah harus menjadi lebih baik. Perbaikan kinerja guru dapat dilakukan dengan meningkatkan disiplin 
kerja dan komunikasi. Dengan adanya disiplin kerja di sekolah diharapkan

kemangkiran

pemborosan tingkat

pemborosan kerja, ditekan seminimal mungkin.

\section{Pembahasan Verifikatif}

Pembahassan verifikatif dimaksudkan untuk membahas perihal pengaruh dan signifikansinya serta, pembahasan keterkaitan teori yang mendukung yang diselaraskan dengan hasil pengolahan data.

a. Pengaruh Komunikasi $\left(\mathrm{X}_{1}\right)$ Terhadap Kinerja guru (Y). Berdasarkan hasil statistik, diperoleh nilai persamaan koefesien kolerasi sebesar persamaan regresi $\mathrm{Y}=$ $9,725+0,408 \mathrm{X}_{1}$ dan nilai koefisien korelasi sebesar 0,703 artinya kedua variabel mempunyai tingkat pengaruh yang kuat. Nilai determinasi atau kontribusi pengaruh komunikasi $\left(\mathrm{X}_{1}\right)$ terhadap kinerja guru (Y) adalah sebesar 0,494 atau sebesar $49,4 \%$ sedangkan sisanya $50,6 \%$ dipengaruhi oleh faktor lain. Hal ini menunjukkan bahwa komunikasi yang meningkat akan meningkatkan kinerja guru. Uji hipotesis diperoleh $\mathrm{t}$ hitung > t tabel atau (5,927 > 2,028), hal ini diperkuat dengan probability signicancy $0,000<$ 0,05 , dengan demikian $\mathrm{H}_{0}$ ditolak dan $\mathrm{H}_{1}$ diterima artinya terdapat pengaruh positif dan signifikan secara parsial antara komunikasi terhadap kinerja guru SDN Parakan Tangerang
Selatan. Hasil penelitian ini konsisten dengan penelitian.

b. Pengaruh Disiplin Kerja $\left(\mathbf{X}_{2}\right)$ Terhadap Kinerja guru (Y)

Berdasarkan hasil statistik, diperoleh persamaan regresi $\mathrm{Y}=9,725+0,351 \mathrm{X} 2$ dan nilai koefisien korelasi sebesar 0,670 artinya kedua variabel mempunyai tingkat pengaruh yang kuat. Nilai determinasi atau kontribusi pengaruh disiplin kerja $\left(\mathrm{X}_{2}\right)$ terhadap kinerja guru (Y) adalah sebesar 0.449 atau sebesar 44,9\% sedangkan sisanya $51,1 \%$ dipengaruhi oleh faktor lain. Hal ini menunjukkan bahwa disiplin kerja yang tinggi akan meningkatkan kinerja guru. Uji hipotesis diperoleh $\mathrm{t}$ hitung $>\mathrm{t}$ tabel atau $(5,412>2,028)$, hal ini diperkuat dengan probability signicancy $(0,000<$ $0,05)$, dengan demikian $\mathrm{H}_{0}$ ditolak dan $\mathrm{H}_{2}$ diterima, hal ini menunjukan bahwa terdapat pengaruh yang positif dan signifikan secara parsial antara disiplin kerja terhadap kinerja guru pada SDN Parakan Tangerang Selatan.

c. Pengaruh Komunikasi $\left(\mathrm{X}_{1}\right)$ dan Disiplin Kerja (X2) Secara Simultan Terhadap Kinerja guru (Y).

Berdasarkan hasil penelitian, menunjukkan bahwa komunikasi $\left(\mathrm{X}_{1}\right)$ dan disiplin kerja $\left(\mathrm{X}_{2}\right)$ berpengaruh positif terhadap kinerja guru dengan diperoleh persamaan regresi $\mathrm{Y}$ $=9,725+0,480 X_{1}+0,351 X_{2}$. Hasil analisis regresi ini menunjukkan koefisien dari 
masing-masing variabel bertanda positif, artinya semakin tinggi komunikasi dan disiplin kerja, maka akan semakin tinggi pula kinerja guru. Sedangkan nilai korelasi atau tingkat pengaruh antara variabel bebas dengan variabel terikat diperoleh sebesar 0,758 artinya memiliki memiliki pengaruh yang kuat. Nilai determinasi atau kontribusi pengaruh komunikasi dan disiplin kerja sebesar $57.4 \%$ sedangkan sisanya sebesar $42.6 \%$ dipengaruhi oleh faktor lain.

Dari pengujian hipotesis diperoleh $F_{\text {hitung }}>F_{\text {tabel }}$ atau $(23,621>2,870)$, hal tersebut juga diperkuat dengan probability significancy $0,000<$ 0,05 . Dengan demikian $\mathrm{H}_{0}$ ditolak dan $\mathrm{H}_{3}$ diterima. Artinya terdapat pengaruh positif dan signifikan secara simultan antara komunikasi dan disiplin kerja terhadap kinerja guru pada SDN Parakan Tangerang Selatan.

\section{PENUTUP}

\section{A. Kesimpulan}

Berdasarkan uraian pada bab-bab sebelumnya, dan dari hasil analisis serta pembahasan mengenai pengaruh komunikasi dan disiplin kerja terhadap kinerja kerja guru, sebagai berikut :

1. Komunikasi $\left(X_{1}\right)$ berpengaruh positif dan signifikan terhadap Kinerja Guru (Y) dengan nila korelasi sebesar 0,703 artinya memiliki pengaruh yang kuat. Koefisien determinasi sebesar 49,4\%. Uji hipotesis diperoleh $\mathrm{t}$ hitung > t tabel atau (5,927> $2,028)$, hal ini diperkuat dengan probability signifikansi $0,000<$ 0,05, dengan demikian $\mathrm{H}_{0}$ ditolak dan $\mathrm{H}_{1}$ diterima artinya terdapat pengaruh positif dan signifikan antara Komunikasi terhadap Kinerja Guru pada SDN Parakan Tangerang Selatan. Disiplin kerja $\left(\mathrm{X}_{2}\right)$ berpengaruh positif dan signifikan terhadap kinerja kerja guru (Y) dengan nilai korelasi sebesar 0,670 artinya memiliki pengaruh yang kuat. Koefisien determinasi sebesar 44,9\%. Uji hipotesis diperoleh $\mathrm{t}$ hitung > t tabel atau (5,412 > $2,028)$, hal ini diperkuat dengan probability signifikansi $0,000<$ 0,05 , dengan demikian $\mathrm{H}_{0}$ ditolak dan $\mathrm{H}_{2}$ diterima artinya terdapat pengaruh positif dan signifikan antara disiplin kerja $\left(\mathrm{X}_{2}\right)$ terhadap kinerja kerja guru (Y) pada SDN Parakan Tangerang Selatan.

2. Komunikasi $\left(\mathrm{X}_{1}\right)$ dan Disiplin kerja $\left(\mathrm{X}_{2}\right)$ berpengaruh positif dan signifikan terhadap kinerja kerja guru (Y) dengan persamaan regresi $\mathrm{Y}=9,725+$ $0,480 X_{1}+0,351 X_{2}$. Nilai korelasi diperoleh sebesar 0,758 artinya variabel bebas dengan variabel terikat memiliki pengaruh yang kuat dengan koefisien determinasi atau pengaruh secara simultan sebesar $\quad 57.4 \%$ sedangkan sisanya sebesar $\quad 42.6 \%$ dipengaruhi faktor lain. Uji hipotesis diperoleh nilai $F$ hitung $>F_{\text {tabel }}$ atau $(23,621>2,870)$, hal tersebut juga diperkuat dengan probability signifikansi 
$0,000<0,05$. Dengan demikian $\mathrm{H}_{0}$ ditolak dan $\mathrm{H}_{3}$ diterima. Artinya terdapat pengaruh positif dan signifikan secara simultan antara komunikasi dan disiplin kerja terhadap kinerja kerja guru pada SDN Parakan Tangerang Selatan.

\section{B. Saran}

1. Variabel komunikasi (X1) pernyataan yang paling lemah adalah pernyataan nomor satu yaitu kepala sekolah mampu memberikan arahan dan masukan pada semua komponen sumberdaya yang ada disekolah dimana hanya mencapai score sebesar 3,74 meskipun termasuk dalam kategori baik namun untuk lebih baik lagi sekolah harus melakukan bimbingan atau latihan khusus untuk sumberdaya yang ada disekolah, agar meningkat menjadi lebih baik lagi.

2. Variabel disiplin kerja (X2), pernyataan yang paling lemah adalah pernyataan nomor dua yaitu aturan organisasi dapat diterapkan dengan baik tanpa tebang pilih dimana hanya mencapai score sebesar 3,74 meskipun termasuk dalam kategori baik namun untuk lebih baik lagi sekolah harus menegaskan peraturanperaturan yang sudah di tetapkan didalam organisasi sekolah, sehingga siapapun yang melanggar aturan menerima hukuman nya.

3. Variabel kinerja guru (Y), pernyataan yang paling lemah adalah pernyataan nomor lima yaitu saya selalu memberikan ide-ide kepada guru lain untuk sistem mengajar dengan baik dimana hanya mencapai score sebesar 3,76 meskipun termasuk dalam kategori baik namun untuk lebih baik lagi sekolah harus mengadakan seminar, guna untuk menambah wawasan tenaga pengajar atau guru dalam sistem mengajar, sehingga murid tidak merasa jenuh dengan proses pembelajaran.

4. Kontibusi pengaruh (determinasi) antara komunikasi dan disiplin kerja secara simultarn terhadap kinerja guru sebesar 0,574 maka dapat disimpulkan bahwa variabel komunikasi $\left(\mathrm{X}_{1}\right)$ dan disiplin kerja (X2) berpengaruh terhadap variabel kinerja guru (Y) sebesar $57.4 \%$ sedangkan sisanya sebesar $42.6 \%$ dipengaruhi oleh faktor lain yang tidak dilakukan penelitian. Oleh karenanya disarankan kepada penelitian berikutnya agar melakukan penelitian yang relevan dengan cara memperbaiki indikator yang masih tidak baik atau dengan menambah indikator pertanyaan dan jumlah responden penelitian sehingga akan dapat lebih diketahui variabel yang paling memberikan kontribusi positif bagi sekolah.

\section{DAFTAR PUSTAKA}

AA. Anwar Prabu Mangkunegara, Manajemen Sumber Daya Manusia Perusahaan, Remaja Rosdakarya, Bandung.2013 
Amstrong dan Baron, Manajemen dan Evaluasi Kinerja Guru. Penerbit Aswajaya Pressido, Yogyakarta, 2014.

Djoko Purwanto, "Komunikasi Bisnis”.Edisi IV, Erlangga, Jakarta, 2011.

H. Edy Sutrisno, M.Si, “ Manajemen Sumber Daya Manusia" Cetakan ke-01, Kencana, Jakarta 2017.

F.X. Suwarto M.S., "Manajemen Kinerja” Cetakan ke-01, Cahaya Atma Pustaka, Yogyakarta, 2014.

George Terry R, Manajemen Sumber Daya Manusia Edisi Revisi. Penerbit PT Bumi Aksara, Jakarta, 2017.
Hasibuan Malayu, Manajemen Sumber Daya Manusia Edisi Revisi. Penerbit PT Bumi Aksara, Jakarta, 2014.

Jhon Fiske, "Pengantar Ilmu Komunikasi" Cetakan ke-3, PT Rajagrafindo Persada, Jakarta 2014.

Rivai Veithzal, Manajemen Sumber Daya Manusia Untuk Perusahaan. Penerbit PT Raja Grafindo Persada, Jakarta, 2015

Sugiyono, "Metode Penelitian Bisnis: Pendekatan kualitatif, kuantitatif dan R\&D" Cetakan ke-13, Alfabeta, Bandung, 2016. 


\section{PANDUAN SINGKAT BAGI PENULIS JURNAL SDM JENIUS}

Panduan penulisan ini dimaksudkan untuk menyeragamkan bentuk penulisan karya ilmiah yang dikirim penulis ke redaksi Jurnal Jenius, dengan panduan penulisan sebagai berikut :

1. Naskah ditulis dalam Bahasa Indonesia dengan Abstrak Bahasa Indonesia dalam bentuk Font 12" dengan ukuran 1 Spasi dengan intisari tidak lebih dari 250 kata disertai 3 atau 4 kata kunci (keyword).

Naskah berupa Softcopy program MS maksimal 25 Halaman termasuk tabel dan gambar, spasi 1.

2. Sistematika penulisan disusun dengan urutan sebagai berikut :

a) Judul, nama dan alamat email penulis/peneliti tunggal.

b) Abstrak dan intisari, keyword dan kata kunci, dibuat dengan 1 kolom.

c) Batang Tubuh :

1). Pendahuluan, termasuk didalamnya intisari permasalahan

2). Perumusan Masalah

3). Tujuan Penelitian

4). Landasan teori termasuk didalamnya hipotesis dan kerangka Pemikiran

5). Metodologi Penelitian

6). Hasil dan Pembahasan

7). Kesimpulan

8). Daftar Pustaka

9). Seluruh isi tersebut di buat dengan 2 kolom

3. Judul ditulis dalam bentuk font Times New Roman 12" dengan huruf besar kecil dicetak tebal dan ditempatkan ditengah halaman,, serta tidak lebih dari 18 kata.

4. Tulisan karya ilmiah dalam bentuk font Times New Roman 12" dengan ukuran spasi 1,0 spasi dalam bentuk kolom.

5. Gambar diberi nomor dan keterangan, sedangkan tabel diberi nomor dan keterangan diatasnya.

6. Penulisan persamaan matematika yang terdapat pada halaman naskah hendaknya menggunakan equation editor.

7. Daftar pustaka hanya memuat literature yang dirujuk dalam keterangan dan dicantumkan pada bagian akhir naskah dilakukan dengan memberikan nomor.

8. Margin atas dan kiri $4 \mathrm{~cm}$, kanan dan bawah $3 \mathrm{~cm}$, dan ukuran kertas A4.

9. Email Redaksi : jenius@unpam.ac.id / jurnalsdm.unpam@gmail.com 